\title{
IMPROVEMENT OF WATER VAPOR BARRIER PROPERTIES OF CHITOSAN-COLLAGEN LAMINATED CASINGS USING BEESWAX

\author{
${ }^{1}$ N. M. Hromiš, ${ }^{2}$ V. L. Lazić, ${ }^{3}$ D. Z. Šuput, ${ }^{4}$ S. Z. Popović, ${ }^{5}$ V. M. Tomović \\ ${ }^{1}$ Faculty of Technology, University of Novi Sad, Bul. Cara Lazara 1, 21000 Novi Sad, R. Serbia \\ e-mail: nevenakrkic@gmail.com
}

\begin{abstract}
Collagen casings are commercially used in sausage production. In this paper, collagen film that is used for sausage casings was laminated with chitosan film to produce barrier casing film.

Chitosan coating was prepared by dissolving chitosan powder in $1 \%$ acetic acid. After dissolving chitosan, caraway essential oil, wetting agent Tween 20 and different amounts of beeswax, from 0 to $25 \mathrm{~g}$ were added to the solution. The solution was coated on collagen film surface in three layers, using a sponge brush to make laminated films. Films were air dried at temperature $\mathrm{t}=23{ }^{\circ} \mathrm{C} \pm 2{ }^{\circ} \mathrm{C}$. Uncoated collagen film was used as reference.

Film thickness, water vapor barrier properties and FTIR spectra were determined. With growing amount of beeswax added to the chitosan layer, film thickness grew from $112 \mu \mathrm{m}$ for laminated film with $5 \mathrm{~g}$ of beeswax to $225 \mu \mathrm{m}$ for film with $25 \mathrm{~g}$ of beeswax, compared to $83 \mu \mathrm{m}$ for collagen film. Water vapor barrier properties improved with growing amount of beeswax in chitosan layer, ranging from $130.71 \mathrm{~g} / \mathrm{m}^{2} 24 \mathrm{~h}$ for laminated film with added $5 \mathrm{~g}$ of beeswax to $66.96 \mathrm{~g} / \mathrm{m}^{2} 24 \mathrm{~h}$ for the film with $25 \mathrm{~g}$ of beeswax, compared to $290.64 \mathrm{~g} / \mathrm{m}^{2} 24 \mathrm{~h}$ for collagen film. Addition of beeswax showed great potential in lowering water vapor permeability of laminated collagen-chitosan film. FTIR spectra could be used to determine quantitative law dependency between added amount of beeswax and spectra absorption values,as well as to prove compactness of chitosan-beeswax layer.
\end{abstract}

Keywords: edible biofilms, chitosan, collagen casings, beeswax, characteristics

\section{INTRODUCTION}

Edible biofilms, which are produced from renewable resources, became trend in the development of packaging materials [19]. Among these films, polysaccharide films based on chitosan were extensively investigated. Chitosan is the name for a group of chitin substituents with low acetilation degree. Monomer units of glucosamine and a percentage of N-acetyl glucosamine in the molecule are linked with $\beta-1,4$ glycoside linkage [5].

Chitosan got a tag GRAS (generally recognized as safe) by the FDA (Food and Drug Administration) in USA, as well as in Norway, Italy, Korea and Japan [25]. It is used in nutrition as a diet fiber, for lowering bad cholesterol level, help for lactose intolerance, and in food industry as emulsifier, color stabilizer, and neutralizer, flavor enhancer, for fruit juice clarification $[14,25,30]$.

Numerous researchers proved chitosan antimicrobial, antioxidant activity, as well as its biodegradability [4, $29,13,14,15,21,23,24,28,33]$.

Because of the possibility to form films, chitosan was investigated in edible coatings and films production. Films showed good barrier properties to gases and good mechanical properties, while high water sensitivity remains an issue to overcome. These results varied in different reports, depending on the chitosan source and its features, used solvents and methods for producing the film, as well as the type and quantity of used plasticizer [14, 16, 31]. In order to improve the water barrier properties, the main lipid fractions incorporated into the base of biopolymer films are fatty acids [32, 35], vegetable oils $[2,6]$, hydrogenated oils [34] and waxes [11].

Chitosan can be used as a carrier for low molecular weight substances that are slowly released from the chitosan network. Many researches are working on active packaging design based on this principle [22, 5, $25,30]$. Antimicrobial and antioxidant activity of pure chitosan film may be improved by incorporating active compounds in the film matrix [8]. Plant essential oils can be considered as a natural alternative to chemical preservatives and their use in foods agrees with consumers demands for safe natural products with minimum chemical aditives [3]. However, wider application of essential oils in food industry is difficult to achieve due to their influence on organoleptic food properties and alterations of their natural 
activity due to interactions with food components $[10,26]$. Caraway essential oil could serve as safe antioxidant and antiseptic supplement in preventing deterioration of foods [27].

Traditional collagen casings are mostly used for dry fermented sausage manufacturing. Regarding to manufacturing process, the desirable properties for traditional collagen casings are: allowing good penetration of flavors and aromas, water and steam permeability and resistance during filling and clipping. When sausage production is finished, further water lost, penetration of aromas and air oxygen becomes undesirable and shortens shelf life of the product [12].

For the above mentioned it might be useful to combine collagen films from casings with a chitosan coating, which should be a good barrier to gasses and protect the surface from microbial growth but its main drawback is sensitivity to moisture and its high water vapor permeability. In this paper, collagen film that is used for sausage casings was laminated with modified chitosan film to produce water vapor barrier biofilm. To improve water vapor barrier properties, beeswax was added to chitosan coating.

\section{MATERIALS AND METHODS}

\subsection{Materials}

\subsubsection{Coating preparation}

Commercial highly viscous chitosan from crab shells was purchased from Sigma-Aldrich Chemical (St. Louis, Missouri, USA). Caraway essential oil was purchased from manufacturer Herba doo (Belgrade, Serbia), glacial acetic acid and Tween 20 were obtained from Superlab (Belgrade, Serbia).

Chitosan coating was prepared by dissolving chitosan powder in $1 \%$ acetic acid to reach chitosan mass per volume ratio of $4 \mathrm{~kg} \cdot \mathrm{m}^{-3}$. Solution was stirred overnight on a magnetic stirrer to dissolve chitosan. After dissolving chitosan, caraway essential oil and wetting agent Tween 20 were added to the solution in $0.8 \%$ and $0.4 \%$ volume concentrations, respectively. Different amount of beeswax $0,5,6,7,8,9,10,11,12,15$, 20 and $25 \mathrm{~g}$ was melted in $30 \mathrm{~mL}$ of distilled water on $65^{\circ} \mathrm{C}$ and added to filmogenic solution. Filmogenic solution was stirred for $5 \mathrm{~min}$ with laboratory stirrer and then coated on collagen film surface in tree layers, using a sponge brush to make laminated films. Films were air dried at temperature $\mathrm{t}=23{ }^{\circ} \mathrm{C} \pm 2{ }^{\circ} \mathrm{C}$. Uncoated collagen film was used as reference.

\subsection{Methods}

Film thickness was measured using a micrometer Digico 1 (TESA, UK) with sensitivity of $0.001 \mathrm{~mm}$. Eight thickness measurements were carried out for each film, and expressed as the mean value \pm standard deviation.

\subsubsection{Water vapor transmission rate (WVTR)}

Water vapor barrier properties of films were determined gravimetrically according to the ASTM E 96-95 desiccant method. Anhydrous silica gel was used to maintain a $0 \%$ atmosphere inside the cells. Distilled water was used to maintain $100 \%$ RH outside the cells.

The ATR-FTIR spectra were recorded at room temperature on a Nicolet iS10 FT-IR spectrometer (Thermo Fisher Scientific, MA, USA). All spectra were taken in the spectral range of $4000-500 \mathrm{~cm}^{-1}$ with a $4.0 \mathrm{~cm}^{-1}$ resolution. Software Omnic 8.1. and TQ Analyst (Thermo Fisher Scientific, MA, USA) were used to operate the FTIR spectrometer, collect and present all the data.

Statistical analysis was carried out using software OriginPro 8.0 SR2. Measurements of each property were made at least in three replicates. All data were presented as the mean value with their standard deviation indicated (mean \pm SD). One-way ANOVA and Bonferoni tests, using a $p \leq 0.05$ level of significance, were applied to compare the means of properties. 


\section{RESULTS AND DISCUSSION}

Results for film thicknesses are shown in Fig. 1. With growing mass of added beeswax, thickness of laminated films grew. Good correlation $\left(\mathrm{R}^{2}=0.9869\right)$ could be withdrawn between these two parameters for the polynomial function of second order:

$$
y=-0,0639 x^{2}+7,4947 x+80,244
$$

This dependence could be also represented with linear function:

$$
y=5,844 x+87,894
$$

having correlation factor over $0.9\left(\mathrm{R}^{2}=0,9791\right)$.

With growing amount of beeswax added to the chitosan layer, film thickness grew from $112 \mu \mathrm{m}$ for laminated film with $5 \mathrm{~g}$ of beeswax to $225 \mu \mathrm{m}$ for film with $25 \mathrm{~g}$ of beeswax, compared to $83 \mu \mathrm{m}$ for collagen film without coating. Similar results were obtained when growing concentration of essential oils (lipophilic phase) was added to chitosan film. Chi reported that addition of $2 \%$ oregano essential oil (OEO) in film-forming solution resulted in more than a 3-fold increase in film thickness [5]. In our previous work, we reported that lamination of collagen film with chitosan film without OEO didn't affect thickness of collagen film, but with OEO addition, thickness values increased significantly. Similar behavior was recorded for unlaminated chitosan films $[17,18]$.
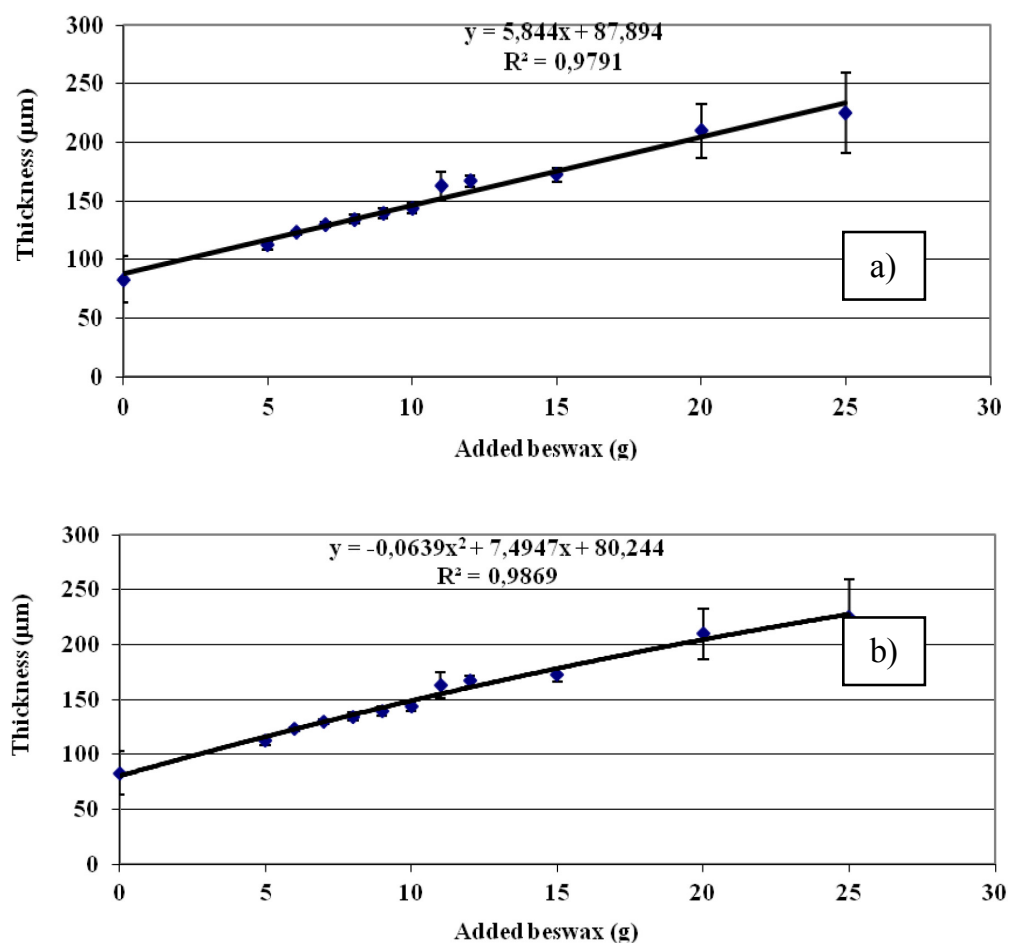

Figure 1. Thickness ( $\mu \mathrm{m})$ of laminated collagen-chitosan films with added growing amount of beeswax (g). a) linear function; b) polynomial function. Vertical bars represent standard deviation 
Water vapor transmission rate (WVTR) for tested films is shown in Fig. 2. Decreasing trend of WVTR with increasing mass of added beeswax can be observed. However, this decrease is not proportional to the added mass of beeswax. With the addition of $5 \mathrm{~g}$ of beeswax to the film, the most pronounced decrease in WVTR was recorded $(\mathrm{p}<0.05)$, from $290.64 \mathrm{~g} / \mathrm{m}^{2} 24 \mathrm{~h}$ for collagen film to $130.71 \mathrm{~g} / \mathrm{m}^{2} 24 \mathrm{~h}$ for laminated film with added $5 \mathrm{~g}$ of beeswax (about 55\% lowering). There were two more points where decrease in WVTR was significant $(\mathrm{p}<0.05)$ and these points were for $10 \mathrm{~g}$ and $25 \mathrm{~g}$ of added wax, having WVTRs of $102.49 \mathrm{~g} / \mathrm{m}^{2} 24 \mathrm{~h}$ and $66.96 \mathrm{~g} / \mathrm{m}^{2} 24 \mathrm{~h}$, respectively.

Addition of beeswax showed potential in lowering water vapor permeability of laminated collagenchitosan film. Similar to our results, incorporation of lipolitic component into hydrophilic film was shown to lower water permeability. Oleic acid, pure or mixed with beeswax, had a plasticizing effect in the films and reduced water vapor permeability, compared to sodium caseinate film without lipids [9]. [2] succeeded in lowering the water vapour permeability (WVP) of chitosan-starch film using palm oil and margarine. Similar results with decreasing WVP of chitosan film were achieved with the incorporation of different lipid fractions (fish oil, vegetable oil, saturated fatty acid and unsaturated fatty acid) [31].

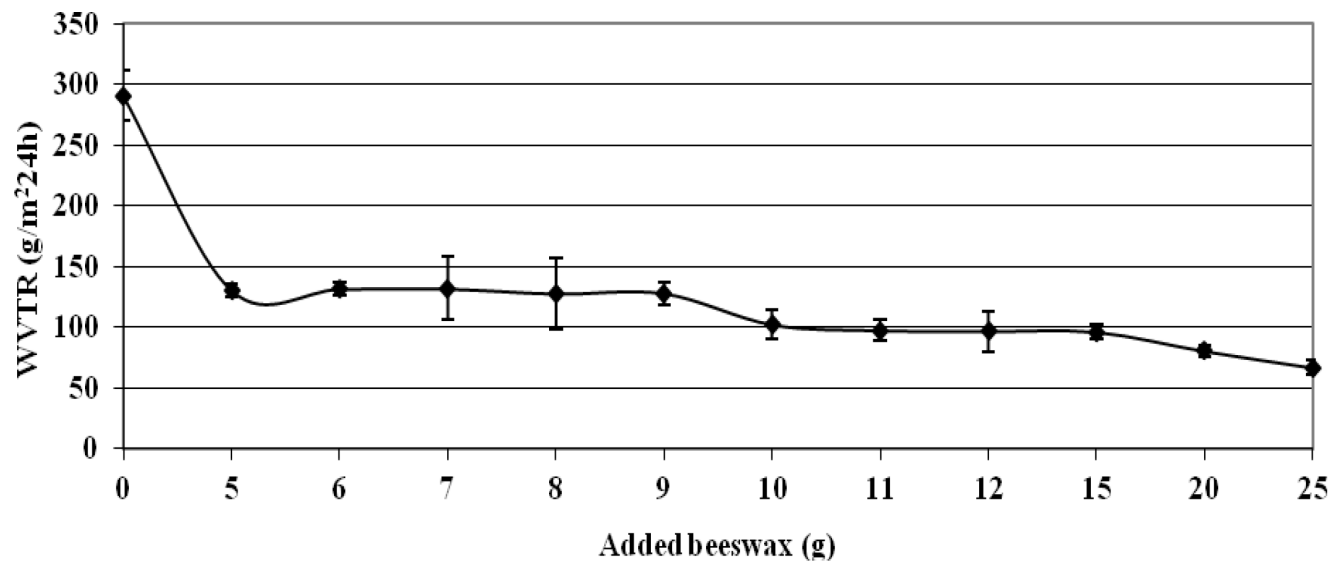

Figure 2. Water vapor transmission rate $\left(\mathrm{g} / \mathrm{m}^{2} 24 \mathrm{~h}\right)$ of laminated collagen-chitosan films with added growing amount of beeswax (g). Vertical bars represent standard deviation

Fig. 3. shows collagen and chitosan-collagen laminated film with $5 \mathrm{~g}$ of beeswax in the chitosan layer, with their correlation. From the shown spectra it could be concluded that coating covered collagen casing completely. Correlation of 0.0801 shows that these are spectra of different materials. 
Qcheck resuts for: collapen

Date: Wad Dec11 11:33:47 2013. (GNT +01.00)

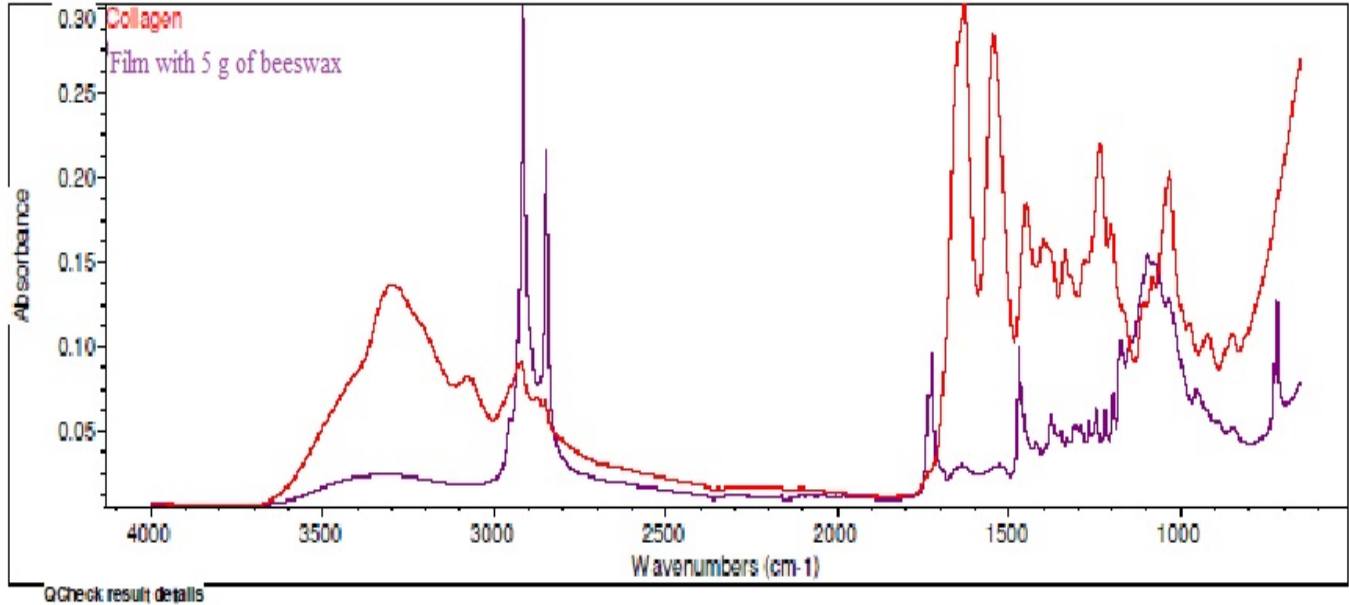

Correlation: 0.0801

OCheck regions: $4000.0-650.0$

Spectrum 1 tite: Collagen

Spectrum 2 tite: Film with $5 \mathrm{~g}$ of beeswax

Figure 3. FTIR spectra of collagen and chitosan-collagen laminated film with $5 \mathrm{~g}$ of beeswax in the chitosan layer, with correlation between the spectra

Spectra of collagen obtains a combination of four spectral intervals: $v(\mathrm{C}=\mathrm{O})$ absorption of amide $\mathrm{I}(1,700$ $\left.1,600 \mathrm{~cm}^{-1}\right), \delta(\mathrm{CH} 2)$, and $\delta(\mathrm{CH} 3)$ absorptions $\left(1,480-1,350 \mathrm{~cm}^{-1}\right), v(\mathrm{C}-\mathrm{N})$, and $\delta(\mathrm{N}-\mathrm{H})$ absorptions of amide III $\left(1,300-1,180 \mathrm{~cm}^{-1}\right)$, and $v(\mathrm{C}-\mathrm{O})$ and $v(\mathrm{C}-\mathrm{O}-\mathrm{C})$ absorptions of carbohydrate moieties $(1,100$ $1,005 \mathrm{~cm}^{-1}$ ) [1].

For the laminated spectra with $5 \mathrm{~g}$ of beeswax, characteristic peaks for the chitosan spectra were identified: a broad band at around $3500-3000 \mathrm{~cm}^{-1}$, for $-\mathrm{N}-\mathrm{H}$ and $\mathrm{OH} \cdots \mathrm{O}$ stretching vibration, as well as intermolecular hydrogen bonding of chitosan molecules, amide I and amide II absorption peaks (N-H bending vibration) at $1633.85 \mathrm{~cm}^{-1}$ and $1540.47 \mathrm{~cm}^{-1}$, a band at $2920.17 \mathrm{~cm}^{-1}$ for $-\mathrm{CH}_{2}$ asymmetric stretching vibration peak, a peak at $1407.68 \mathrm{~cm}^{-1}$ corresponding to $-\mathrm{C}=\mathrm{O}$ stretching (amide I) and peaks at $1022.69 \mathrm{~cm}^{-1}, 1066.46 \mathrm{~cm}^{-1}$ and $1150.70 \mathrm{~cm}^{-1}$ due to $-\mathrm{C}-\mathrm{O}$ stretching and $-\mathrm{OH}$ deformation vibrations [20; $36 ; 31 ; 7]$. In addition to this, absorption bands appeared at $1736.28 \mathrm{~cm}^{-1}$, originating from $\mathrm{C}=\mathrm{O}$ saturated absorption and $\mathrm{CH}_{2}$ scissor vibration band appeared at 1472.27 and $1462.59 \mathrm{~cm}^{-1}$ [36]. 


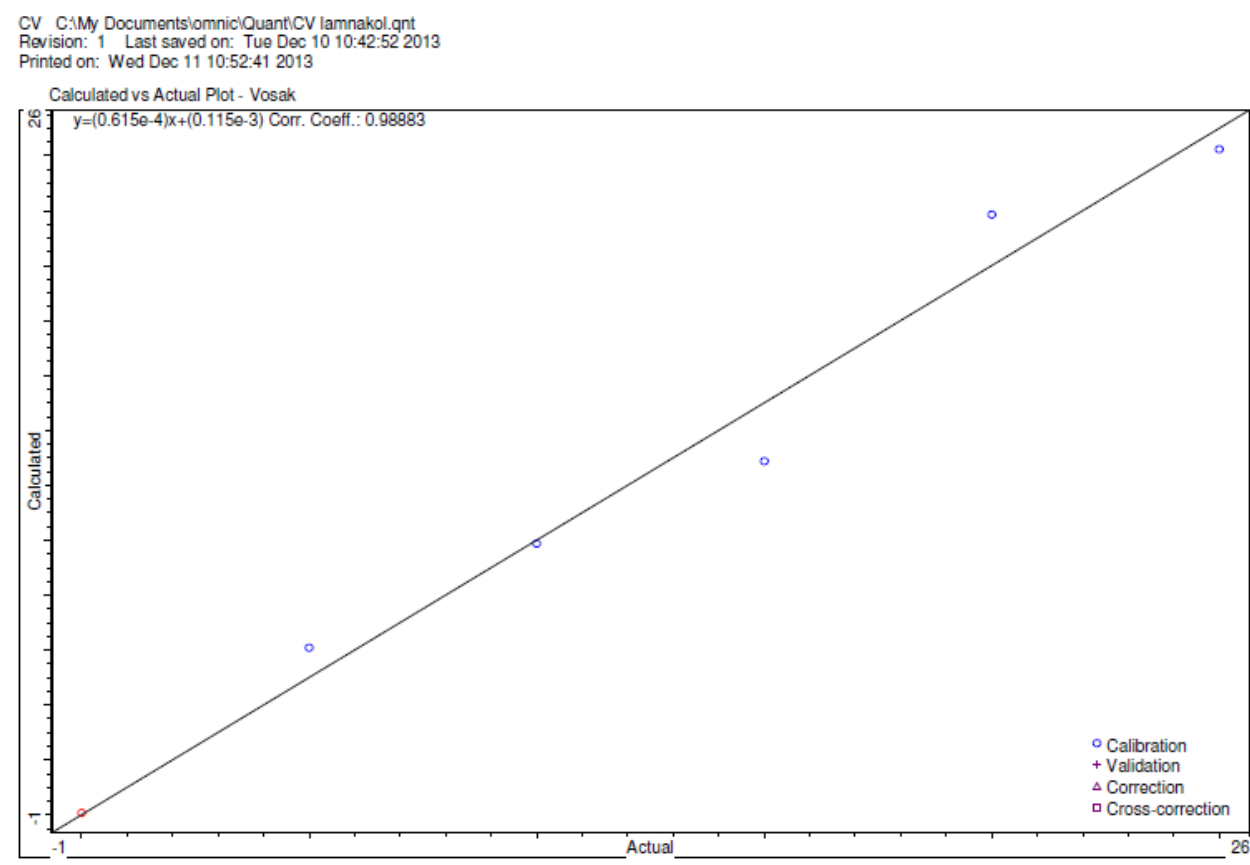

Figure 4. Calculated verses actual values plot for Simple Beer's law performed on spectra of laminated films with growing amount of beeswax

Using software TQ Analyst, quantitative analysis Simple Beer's law was performed on spectra of laminated films with growing amount of beeswax in the spectral region of $3871.40-3868.50 \mathrm{~cm}^{-1}$. Calculated verses actual values, shown in Fig. 4 showed very good correlation $\left(\mathrm{R}^{2}=0.98883\right)$ for the linear function:

$$
y=0.615 \mathrm{e}^{-4} \mathrm{x}+0.115 \mathrm{e}^{-3}
$$

Functional dependency, described by this equation, was determined between the amount of added beeswax and the FTIR spectra of laminated collagen-chitosan films with growing amount of beeswax in the chitosan layer, in the spectral region of $3871.40-3868.50 \mathrm{~cm}^{-1}$.

\section{CONCLUSION}

When growing amount of beeswax, as a lipophilic phase, was added to the chitosan layer of chitosanlaminated collagen film, film thickness grew significantly. Thickness grew for about $25 \%$ to $63 \%$ when different mass of beeswax was added. Addition of beeswax showed significant potential in lowering water vapor permeability of laminated collagen-chitosan film. Water vapor transmission rate was lowered up to $77 \%$ with the addition of beeswax. Functional dependency was determined between the amount of added beeswax and the FTIR spectra of laminated collagen-chitosan films. FTIR also showed continuity of chitosan-beeswax layer. Further work should be carried out to determine the effect that beeswax shows on other relevant properties of chitosan coating: sensory, mechanical and gas barrier.

\section{ACKNOWLEDGEMENT}

This study was supported by the Provincial Secretariat for Science and Technological Development, Autonomous Province of Vojvodina, Republic of Serbia, project No. 114-451-3464/2013-02. 


\section{REFERENCES}

[1] Belbachir, K., Noreen, R., Gouspillou, G., Petibois, C. (2009). Collagen types analysis and differentiation by FTIR spectroscopy. Analytical and Bioanalytical Chemistry, 395, 829-837.

[2] Bourtoom, T., Chinnan, M.S. (2009). Preparation and properties of rice starch chitosan blend biodegradable film. LWT - Food Science and Technology, 41, 1633-1641.

[3] Burt, S. (2004). Essential oils: their antibacterial properties and potential applications in foods - a review. International Journal of Food Microbiology, 94, 223-253.

[4] Chhabra, P. (2004). Antimicrobial and Antioxidant Properties of Chitosan, A Master Degree Thesis, Graduate Faculty of The University of Georgia, USA.

[5] Chi, S. (2004). Development and Characterization of Antimicrobial Food Coatings Based on Chitosan and Essential Oils. A Master Degree Thesis. The University of Tennessee, Knoxville, USA.

[6] Chi, S, Zivanovic, S., Penfield, M.P. (2006).Application of chitosan films enriched with oregano essential oil on bologna- Active compounds and sensory attributes. Food Science and Technology International, 12, 111-117.

[7] Dilamian, M., Montazer, M., Masoumi, J. (2013). Antimicrobial electrospun membranes of chitosan/poly(ethylene oxide) incorporating poly(hexamethylene biguanide) hydrochloride. Carbohydrate Polymers, 94, 364- 371.

[8] Dutta, P.K., Shipra, T., Mehrotra, G.K., Dutta, J. (2009). Perspectives for chitosan based antimicrobial films in food applications. Food Chemistry, 114, 1173-1182.

[9] Fabra, M.J., Talens, P., Chiralt, A. (2008). Tensile properties and water vapor permeability of sodium caseinate films containing oleic acid-beeswax mixtures. Journal of Food Engineering, 85, 393-400.

[10] Gutierrez, J., Barry-Ryan, C., Bourke, P. (2008). The antimicrobial efficacy of plant essential oil combinations and interactions with food ingredients. International Journal of Food Microbiology, 124, 91-97.

[11] Hambleton, A., Debeaufort, F., Bonnotte, A., Voilley, A. (2009). Influence of alginate emulsion-based films structure on its barrier properties and on the protection of microencapsulated aroma compound. Food Hydrocolloids, 23, 2116-2124.

[12] Hromiš, N., Šojić, B., Škaljac, S., Lazić, V., Džinić, N., Šuput D., Popović S. (2013). Effect of chitosan-caraway coating on color stability, lipid oxidation of traditional dry fermented sausage. Acta periodica technologica, 44, 57-65.

[13] Jeon, Y.J., Shadidi, F., Kamil, J.Y.V.A. (2002). Antioxidative activity of chitosans of different viscosity in cooked cominuted flesh of herring (Clupea harengus). Food Chemistry, 79, 69-77.

[14] Kandasamy, N. (2005): Development and Characterisation of Antimicrobial Edible Films from Crawfish Chitosan. A Dissertation, Graduate Faculty of the Louisiana State University, USA.

[15] Kim, K.W., Thomas, R.L. (2007). Antioxidant activity of chitosans with varying molecular weights. Food Chemistry, 101, 308-313.

[16] Krkić, N., Lazić, V., Gvozdenović, J. (2011). Chitosan biofilm properties as affected by the addition of oregano essential oil. Journal on Processing and Energy in Agriculture (former PTEP), 15, 165-168.

[17] Krkić, N., Lazić, V., Petrović, Lj., Gvozdenović, J., Pejić, D. (2012). The properties of chitosanlaminated collagen film. Food Technology and Biotechnology, 50, 483-489.a

[18] Krkić, N., Lazić, V., Savatić, S., Šojić, B., Petrović, Lj., Šuput, D. (2012). Application of chitosan coating with oregano essential oil on dry fermented sausage, Journal of Food and Nutrition Research, $51,60-68 . \mathrm{b}$

[19] Lazić, V., Novaković, D. (2010). Ambalaža i životna sredina, Univerzitet u Novom Sadu, Tehnološki fakultet, Novi Sad, Srbija.

[20] Leceta, I., Guerrero, P., de la Caba, K. (2013). Functional properties of chitosan-based films. Carbohydrate Polymers, 93, 339- 346.

[21] Nicholas, T.A. (2003): Antimicrobial Use of Native and Enzymatically Degraded Chitosans For Seafood Applications. A Master Degree Thesis, The University of Maine, USA. 
[22] Ojagh, S.M., Rezaei, M., Razavi, S.H., Hosseini, S.M.H. (2010). Development and evaluation of a novel biodegradable film made from chitosan and cinnamon essential oil with low affinity toward water. Food Chemistry, 122, 161-166.

[23] Ouattara, B., Simard, R.E., Piette, G., Bègin, A., Holley, R.A. (2000). Inhibition of surface spoilage bacteria in processed meats by application of antimicrobial films prepared with chitosan. International Journal of Food Microbiology, 62, 139-148.

[24] Papineau, A.M., Hoover, D.G., Knorr, D., Farkas, D.F. (1991). Antimicrobial effect of water-soluble chitosans with high hydrostatic pressure. Food Biotechnology, 5, 45-57.

[25] Prashanth, K.V.H., Tharanathan, R.N. (2007). Chitin/chitosan: modifications and their unlimited application potential-an overview. Trends in Food Science \& Technology, 18, 117-131.

[26] Rojas-Graü, M.A., Soliva-Fortuny, R., Martín-Belloso, O. (2009). Edible coatings to incorporate active ingredients to freshcut fruits - a review. Trends in Food Science \& Technology 20, 438-447.

[27] Samojlik, I., Lakić, N., Mimica-Dukić, N., Đaković-Švajcer, K. and Božin, B. (2010). Antioxidant and hepatoprotective potential of essential oils of coriander (Coriandrum sativum L.) and caraway (Carum carvi L.) (Apiaceae). Journal of Agricultural and Food Chemistry, 58, 8848-8853.

[28] Sebti, I., Chollet, E., Degraeve, P., Noel, C., Peyrol, E. (2007). Water sensitivity, antimicrobial, and physicochemical analyses of edible films based on HPMC and/or chitosan. Journal of Agricultural and Food Chemistry, 55, 693-699.

[29] Sébastien, F. Stéphane, G., Copinet, A. and Coma, V. (2006). Novel biodegradable films made from chitosan and poly(lactic acid) with antifungal properties against mycotoxinogen strains. Carbohydrate Polymers, 65, 185-193.

[30] Shahidi, F., Kamil, J., Arachchiand, V., Jeon, Y-J. (1999). Food applications of chitin and chitosans. Trends in Food Science \& Technology, 10, 37-51.

[31] Souza, V.C., Monte, M.L, Pinto, L.A.A. (2011). Preparation of biopolymer film from chitosan modified with lipid fraction. International Journal of Food Science and Technology, 46, 1856-1862.

[32] Srinivasa, P.C., Ramesh, M.N., Tharanathan, R.N. (2007). Effect of plasticizers and fatty acids on mechanical and permeability characteristics of chitosan films. Food Hydrocolloids, 21, 1113-1122.

[33] Sudharsan, N.R., Hoover, D.G., Knorr, D. (1992). Antibacterial action of chitosan. Food Biotechnology, 6, 257-272.

[34] The, P.D., Debeaufort, F., Voilley, A., Luu, D. (2009). Influence of hydrocolloid nature on the structure and functional properties of emulsified edible films. Food Hydrocolloids, 23, 691-699.

[35] Vargas, M., Albors, A., Chiralt, A., González-Martínez, C. (2009). Characterization of chitosan-oleic acid composite films. Food Hydrocolloids, 23, 536-547.

[36]Zivanovic, S., Li, J., Davidson, P.M., Kit, K. (2007).Physical, mechanical, and antibacterial properties of chitosan/PEO blend films. Biomacromolecules, 8, 1505-1510. 